\title{
Impaired Governance: Limiting Communities' Access to Service Delivery System in Nepal
}

Leshav Acharya

\begin{abstract}
This paper examines governance impairing at the grassroots level that has limited the communities' access to basic services in Nepal. Primary data were collected from 110 locally constituted communitybased organisations that employed 110 organisational surveys and three focus group discussions. Result indicates that the overall practice of governance at the community level remained weak to moderate due to a number of reasons. Firstly, many communities were influenced by power based socio-economic structure. Secondly, some communities were impressed by power politics and interests. Thirdly, many communities were facing biggest crisis of low capacity and resource constraints. Such crisis has been a foremost obstacle in the working culture of communities so they were unable to embrace governance mechanism in their development undertakings.
\end{abstract}

Keywords: Community governance; community-based organisation; service delivery.

\section{Introduction}

Governance is an act of governing that relates to power and performance of actors (Hamilton, Miller, \& Paytas, 2004). It is a self-organising and self-motivating process of state and non-state organisations within a decentralised structure (Halachmi, 2005). A development oriented governance system creates an institutional environment of relationships with outside stakeholders that ensure the quality of services and number of desired values such as rule of 1 aw, accountability, transparency, sound judicial system, an efficient and responsive bureaucracy, a participative policy process, free media and incorporation of market principles (Zafarullah and Huque, 2001; Rhodes, 1996). Many neoliberals believe that 
governance is a balanced approach towards power, authority and responsibilities, the decision making system (inclusion/exclusion), and the responses of citizens and other stakeholders about each other's roles and functions (Lockwood et al., 2010). In addition, itdeals about the power structures, relationships, accountability, patterns of influence, network structures, and their enforcement (Bingham, Nabatchi, \& O'Leary, 2005).

Nevertheless, many developing countries of the world are faced by accentuate crisis of governance during the 1960's due to market failure, which created institutional crises, governance failures and democratic catastrophes in the world arena mainly in Africa, Latin America, and some of the parts of Asia (Bowles \& Gintis, 2002). Kohli (2004) points out that the neo-patrimonial ties in Africa, clientelistic patterns in Latin America, and colonial setup in the Asia were caused to institutional crises and governance failures. In 1970 s, a common realisation was made through neo-liberalisation (privatization, denationalization and deregulation) to address the institutional crisis and recover the national economic growth through improved governance (Beeson \& Islam, 2005). However, experience shows the governance remains rampant, exclusionary, and unaccountable from social, economic, and political points of view (Tamang \& Malena, 2011). Despite such malpractices, many governments tried to transform their policies, legal provisions and strategies towards people-centered development, democratic rule, and good governance through legislation after late 1980s (Mehrotra, 2006).

In Nepal, neo-liberalization within the framework of Structural Adjustment Program (SAP) was espoused in the late 1980s that created scope of decentralising power and functions of state into alternative structures (Frankel, 2009). Under this framework, Nepal adopted an 'open market economy' and attempted to deliver services through the private sector, NGOs and other non-governmental actors. However, all of these restructuring programs and policies created a serious threat to social justice, social cohesion, and local democracy in Nepal. Murray (2012) argues that the major deficiency of SAP was paying priority only to the self-regulating market machineries, and individual freedom including personal 
well-being, and optimum utilisation of commodities. These actions have essentially led to manipulate the governance and fail to create the social and economic safety nets to the marginal communities. In many instances, it is influenced by power and control mechanism. People's participation in these societies is facing a serious challenge from elitism as general people, who have lack of knowledge and organisation; they are at risk of 'elite capture', power relationships, weak peoples organisations, absence of participatory skills and level of participation, apolitical behaviour, and resource paucity (Gaventa, 2004).

Additionally, there are some common phenomena, which are injecting to the central and local authorities to poor performance; they are policy biases, political capture, corruption, weak bureaucratic performance, and weak institutional framework (Dahal, 2010). In addition, numerous factors deter effective implementation of decentralisation policy and programs. First: the institutional structure and decision making processes of the "centre" is incapable, disorganized and weak. There is lack coordination between two departments under the same ministry (Adhikari \& Lovett, 2006). Second, the organisational structure of local government is unclear and not accountable to the local people (Khanal, 2006). Similarly, a huge resources and opportunities channeled through local bodies are captured by a limited group of people, leaving the majority out of the development mainstream. Thus, the socio-economic situation of a large number of people has deteriorated and they became dissatisfied with the establishment of the country (Agrawal \& Gupta, 2005). Evidence from Africa, Asia and Latin America (Bardhan, 2002; Santiso, 2001) suggests that without good governance, rule of law, predictable administration, legitimate power, and responsive regulation, no amount of funding or no amount of charity has limited the communities' access to basic services. Following the context, this paper examines causes of governance impairing and its effect at the community level for limiting their access to service delivery in Nepal. 


\section{Theoretical Discussion}

Service delivery is a development function, which is distributed by individuals, groups, people's institutions, state or non-state organs, to serve the people for better livelihoods (Shah, 2005). In any regimes, the goal of service delivery system is protecting and upgrading the economic and social well-being of citizens under the principles of equitable distribution, and welfare perspective. In policy discourse, many theories have been introduced across the world to deliver the services, which provide conceptual foundations of understanding of the structure, relationships and the pattern of service delivery. In 1950, a research article 'An Outline for General Systems Theory' was published in the British Journal for the Philosophy of Science that formally describes about organisational structures, functions, and their interactions and associations with the external environment (Kerno, 2008). In the community context, the components (the communities) integrate through many interactions (by way of members) into a single system (community based organizations), which are empowered for service delivery. Although the community service system is a complex mechanism, the numbers of activities, clients and actors are directly and indirectly involved and often pursue their own interests. Some authors (Ramo \& Clair, 1969) argue that it is a highly mechanical, quantitative and objective process, that relates only to input-output relationships, whereas the social aspects and social organisations are more flexible.

Subsequently, institutional theories, as they emerged in the 1970s, focus on institutions which interact and the way they affect society (Meyer, 2008). According to North (1994), it builds the organisational capability to rule and govern society by observing organisations, their formation, internal settings, influences, social values, and political and economic actions. In service delivery perspective, institutional theory includes four different levels of community engagement. These are: embeddedness (traditions, ethics, norms and values); institutional process (execution, legislation, judiciary, and organisational rules and regulations); governing system (management structures); and resources management (Reydon, 2006; Török, 2005). Such levels are closely 
connected with institutions, their practices and rules, actors, power and functional arrangements, and control and mobilisation of resources. However, the weak capability of organisations to design sound policies, institutional imperfection in the service mechanism, skepticism, less priority on structural issues, poor network and association, increasing elite intervention in the organisational structure, less priority to the client service, and highly compartmentalised (top-down) doctrine contribute to the failure of the effective service delivery.

Successively, capability theory explains two basic normative approaches. These are the freedom to achieve well-being in terms of a basic moral position and capabilities (Iversen, 2003; Sen, 1990). Amartya Sen introduced the capability approach, based on the Aristotelian theory of political distribution and human flourishing (Clark, 2005; Saito, 2003). Sen pays more attention to capabilities and commodities through the distinction of 'means and ends', 'functionings and capabilities', and 'freedom of public choice' (Sen, 2004). The means are the inputs of capability, whereas the ends are interpersonal capabilities of various 'doings' and 'beings' (Migheli, 2011). Functionings deal with the ability of individuals or organisations to achieve the ends that are enabled by means or different types of inputs, such as non-market, market, and public welfare inputs (Saito, 2003). In developing societies, people are deprived from access to basic entitlements, such as high-quality education, genuine political participation and community activities (Walker, 2005). However, current trends show that communities without roles and responsibilities, adequate resource capacities, and an enabling environment, are unable to make choices relating to basic services.

Past experience shows the prescribed theories were more topdown oriented and thus failed to ensure the effective delivery of services or involve multi-actors in the service mechanism. In the late 1980s, the neoliberal agenda was enacted under enforcement of the Washington Consensus, which focuses on liberal markets, allocative efficiency, and client-oriented service delivery (Fox, 1993). Thorsen and Lie (2000) identify four basic elements of neoliberalism. First, it reconceptualised the role of government. 
This describes the state as a safeguard which has created safety nets to encourage stakeholders' involvement in service delivery functions in a more competitive system. Second, it emphasises on decentralisation and a 'flexible' private sector with greater degrees of freedom and choice. Thirdly, neoliberalism counters domestic economic obstacles and strongly advocates foreign investment. Lastly, neoliberalism is well-matched with 'Keynesian' policy to increase economic growth, by cutting taxes and subsidies and lowering the interest rates in the financial sector. In the community perspective, neoliberalism has brought together two reverse discourses, such as individualism and community, by highlighting the governing community (Cheshire \& Lawrence, 2005). However, experience shows that the emphasis of neoliberalism lay in a set of economic policies, which paid no attention to recognising that the 'social', or 'community' had created barrier to community people in participating in the service delivery mechanism.

In contrast Huntington (1991) promoted the idea of third wave democracy to address the new challenges into the existing system mainly in developing countries. Although it has not enforced the people to participate in the service mechanism, its encouragement approach offers research scholars, development practitioners, and policy makers to re-theorise public policies in order to meet public needs in the changing context of the society. The paradigm shift is also evident that only the responsive governance can create a new avenue in promoting peoples' awareness of their position in society in terms of participation and empowerment (Bekkers, 2007). Additionally, it creates a path for communities, citizens and their institutions to make decisions, take actions and share benefits while governing, guiding, steering, controlling or managing basic services. Conversely, communities in developing countries are usually characterised by disorganised, disintegrated or low technical, human and resource capacity, economic vulnerability, difficulties in accessing basic services and resources, elite controlled and greater degree of exclusion (Shah, 2007). In these societies, the influence of service delivery is not only led by a single factors, but also contributed by different sets of factors such as institutional crisis, poor governmental performance, power arrogation and 
unaccountable leadership, lack of transparency, absence of interest representation in decision making structures, and most notably rampant corruption. Ojha et.,al., (2009) refer the complex interplay of power and knowledge among diverse groups of actors are impeding factors for effective governance.

Furthermore, Conway and Chambers (1992) and Korten (1996) advanced the participatory concept, which come to view as a powerful tool for analysing service delivery systems (Perez., 1999). This tool focuses on participation, ownership, power sharing, control, service quality, social justice and interdependence between stakeholders (McEwan, 2003). By applying these processes, community involvement, downward accountability, influence and control over policy process, resources and service mechanisms have been confirmed (Scott and Fannin, 2007). However, outmoded administrative systems become unable to deliver goods and services to the people efficiently and effectively. The major reasons are inefficiency of the bureaucracy, corruption and cronyism, political interference in public management, and violation of the rule of law and fundamental rights (Zafarullah and Huque, 2001). These have led public sectors impaired from fragmentation and lack of steering and accountability.

Rhodes (1996) proposes the adoption of New Public Management to get rid of the hollowing process through two dimensions. First, managerialism refers to the application of private sector management principles in the public sphere. It stresses handson professional management, explicit standards and measures of performance, managing by results, and value for money and, closeness to customers. Second, new institutional economics mentions to incentive structures such as market competition into public service provision. In doing so, New Public Management stresses the disaggregation of bureaucracies, greater competition and rational choices (Rhodes, 1996). However, development management suffers from poor implementation capacity, coordination problems between discrete agencies and a lack of synergy between public and nongovernmental organizations.

Commins (2007) systematically lists range of factors that affect community governance and service delivery. These include: 
social, political and economic exclusion; economic differentiation; information asymmetry; and socio-economic disparity. Some authors point out that the lack of enabling environment (legal provisions, decentralised policies and strategies, and good governance), bureaucratic complexities (power devolution, partnership development, and working in coordinative actions), confronting interests of partners, and bias are major hindrances of community governance effectiveness (Matunhu, 2011; Uphoff, 2004; Zafarullah \& Huque, 2001).

Additionally, social factors mainly structural causes such as exclusion(feudal legacy, exploitation, and social discrimination), modernisation (technology and globalisation), westernisation (neoliberal agendas), and marketization (competition) are diminishing effectiveness of community governance (Illing \& Gibson, 2007; Upreti \& Müller-Böker, 2010). Political factors, such as power structure (political and social elitism), patron-client relationships, political system, and neo-colonial policies are also influencing community governance (Lewis \& Kanji, 2009; Malla, 2001; Vidal \& Keating, 2004). Other explanations include economic factors such as poverty and deprivation including vulnerability, seasonality, powerlessness and humiliation, lack of skills and knowledge for optimum utilisation of local resources (Chambers, 1995), lack of equal resource distribution, and lack of fair benefit distribution (Mahanty, Guernier, \& Yasmi, 2009), and financial resources crisis are also notable factors (Coombs, 2007).

Stoker (1998) further argues that civil society is constituted of voluntary organisations for tackling collective concerns without reliance on the formal resources of government. The development of a strong and vibrant civil society provides opportunities to the state, people, market and communities to move forward in people's welfare on the right track. The major responsibility of civil society is to maintain social accountability and raise public voices against inefficiency and ineffectiveness. The experience of more developed countries suggests that a vibrant civil society is able to keep local governments in check and enhance downward accountability (Nsubuga \& Olum, 2009). However, in many developing countries, civil society is still crystallising and unable to take on the role it is 
expected to play. Unstable political situation and often corruption within civil society groups have led to distrust in society of their role and agenda. In some places, they seem to be indifferent of their proper functional responsibilities (Roy, 2008).

More recently, governance has been influenced by innovation of technology, information and communication (Carter \& Bélanger, 2005). Escobar (1988) identifies six factors that influence the effectiveness of governance: orthodox institutions and their rigid roles and relationship; manipulation in political, economic and social empowerment agendas; access difficulties for communities to local service system; weak technical and financial capacity of community organisations; public apathy in governance roles; and overbearing traditional power structure of the communities.

Upon such explanations, many are point out about unwounding state of governance in delivering effective services in developing countries. However, many of these are narrowly focused on certain particular issues, while others are too general to be linked to community concerns with governance. For example, Banner (2002) describes the disenchantment of many grassroots actors who view governance as upward accountable and thus susceptible to uncertainties. In such a condition, it cannot ensure "safety net below the safety net"as the resource crisis at the grassroots forces them to rely on external actors, who are by nature more bureaucratic and prefer a hierarchical structure that has the potentiality to threaten the governance system. On the contrary, Cheshire (2000) believes that central and local government commitment, engagement of the private sector, and community cooperation can help achieve governance effectiveness. Weber et al. (2001) explain that major shifts in governance occur as outcomes of three elements: policy discourse, policy actors, and policy instruments-all of which are influenced by events or episodes and institutional performance.

Some authors (Pillora \& McKinlay, 2011; Vongalis-Macrow, 2004) suggest that globalisation (beyond the territory), marketization (competition), and modernisation (information and technological development) have often driven priorities and agendas from community-centred imperatives to those more relevant to society. For this; governance can hardly compete with the public sector 
and market forces. Stâhlberg (1997) argues that it has always faced problems of legitimisation and has been unable to make institutional shifts(single to multiple) or system transformation (top-down vs. bottom-up). Often these create hierarchical structures and empower nominated leaders rather than citizens from the process.

In Nepal, government initiatives to strengthen governance were begun since 1960s through reforming legal provisions and formulating legislations in order to make community service delivery at the grassroots level more effective. However, the people were not convinced of these efforts due to the complexity of the bureaucratic structure and procedures and the centralised trickle down approach (Baral, 2012). A new democratic constitution was promulgated in 1991, which ensured, among other things, good governance, cooperation with the civil society, human rights and freedom of expression. Under the new democratic constitution, different endeavours were made to make effective decentralization and good governance. Among the various efforts, the Local Self-Governance Act and its by-laws (1999) was a milestone for community development. The Act provisioned broad based organisational structure, devolution of authorities, special provision to include women and disadvantaged communities, planned development process and judicial authorities for local bodies. However, criticisms about the effective implementation of LSGA and its Bylaws remain. Weak capability of state and non-state stakeholders to formulate the plan and policies; lack of political commitment; strong influence of political parties and central level bureaucratic management; controlled mechanism in resource mobilisation and management have induced LSGA to fail in addressing community level issues (Dhungana \& Wagle, 2013).

Apart from legal practices, efforts have been made to make effective community service delivery at the grass roots level through strategic planning. During the Eight Plan period, the decentralisation approach was adopted and much more focus was given to empower, strengthen and promote the local government and CBOs to efficiently deliver services at the grass roots level. However, due to many political and administrative hassles and the top down political system, local government institutions and 
community initiatives were not appreciated properly for local service delivery. As milestone of poverty reduction through efficient service delivery, the Ninth Plan (1997-2001) and Tenth Plan (20022007) highlighted decentralisation, participatory development and good governance.

A Poverty Reduction Strategy Paper (PRSP) was developed aiming at reducing poverty from 38 to 30 percent through four pillars: broad based economic growth, social sector development with human development, targeted programs with emphasis on social inclusion, and improved governance (NPC, 2003). Hence, the expectation of the plan was to successfully delivering basic services, enhancing the quality of life of the poor people and promoting economic and social inclusion of deprived communities and regions. The Three Year Interim Plan (2007/08-2009/10) is also expected to reduce the gap between the rich and the poor and improve the relationship between the people/community and state.

However, the state designed techno-bureaucratic pathology and stringent regulations have limited communities' inclusivity and their roles in community resources management (Ojha, 2006). In addition, number of other factors such as institutional vacuums, patrimonial power structures,political and social patronage, fragmented political cultures, disenchanted bureaucracies, lack of adequate information, depressing economic performance, political and bureaucratic capture of power and resources, centralized delivery systems, lack of openness and institutional autonomy,and absence of cultural factors in development that impinge upon community cohesion, structural social inclusion, organisational resources and knowledge, and physical and human capacities are triggering to ineffective governance (Dahal, 2010; Grindle, 2007; Bardhan \& Mookherjee, 2005; Ross \& Osborne, 1999). On the other hand, the effectiveness of governance depends on efficient functioning of several variables such as inclusive participation, the empowerment agenda, process of transparency and accountability, enabling environment, the practice of local democracy, the service delivery system, service integrity mechanisms, social capital development, institution building tools, community mobilisation activities, planning, implementing and monitoring process, 
institutional schemes (both formal and informal), and coordination, linkages and partnerships between development agencies activities.

\section{Methodology}

Purposively, five Village Development Committees (Pawannagar, Shantinagar, Hekuli, Goltakuri and Phulbari) at the lowest unit of local government of Dang district Nepal were chosen for the study. These remotely located places are known for the endemic poverty of their people who are enduringly marginalised from the basic service delivery structures. There the ultra-poor and poor households constitute more than 60 percent of the population. Similarly, service facilities, such as safe drinking water and sanitation,being accessed by these households constitute 33.52 and 43.60 percent respectively (Water Aid, 2012). The education status shows that 59.38 percent people are literate. The involvement of local government bodies, sectoral line agencies, donors and NGOs in these localities has a long history.

For the sample, 110 groups were chosen from three broad CBO categories. They were: 31 Community Forestry User Groups, 53 Community Development Organisation Groups, and 26 Women Development Groups. The Community Forestry User Groups were directly involved in natural resource management activities as per government regulations while the community development organisation groups conducted social, economic and infrastructural development activities at the grassroots level, supported by local government and other development partners. Women development groups ensured women's participation and gender inclusion in local development activities at the grassroots level. Overall, the aim of these groups was to promote community governance to facilitate the peace-building process.

A mixed method approach was adopted that triangulated both quantitative and qualitative techniques for data collection, analysis and presentation. Eight different parameters with 40 indicators were designed by employing a participatory consensus in group meetings. Experience indicates that such parameters are functional activities of the $\mathrm{CBO}$ groups, which were developed under the criterion of governance at the grassroots level. 
Both secondary and primary data were collected. Whereas 110 organisational surveys, and 90 minutes focus group discussions (FGDs) in three different places were administered for the primary data collection. Additionally, institutional records, such as government policies, government Acts, operational plans and minutes of group meetings were collected for the secondary data. Research ethics standards, as set out in the guidelines for Human Research Ethics at the University of New England, Australia applied to the processing of the primary data collection. The researcher gained approval for all components of the research, the organisational survey and focus group discussions.

For the data analysis, both quantitative and qualitative techniques were applied. A composite index technique was employed to analyse the quantitative data that measures responses with respect to a scaling method. The following composite index technique (Booysen, 2002) was administered to analyse the quantitative data: $\mathrm{Cj}=\sum \sum \mathrm{Wi} / \mathrm{nI}$

$\mathrm{Cj}=$ Composite Index Technique of activities, weight given to individual institutions as per the performing activities, $\mathrm{Wi}=1$ and 0 ( 1 = activities performed, $0=$ Not Performed $)$, $\mathrm{n}=$ Number of organisations under the particular categories and, $\mathrm{I}=$ Number of indicators taken under each category of broad functional groups.

This method assists to measure and compare the organisations' contribution and performance in the different service activities. Based on composite index values, the CBOs' contribution was categorised into four classes, as follows: efficient=above 0.75, moderate $=0.50-0.75$, weak $=0.25-0.50$ and very weak $=$ less than 0.25 . Later, the quantitative result was triangulated by employing qualitative data analysis.

\section{Findings and Results}

In every society, emergence of community based organizations has explored the new prospects and possibilities. In Nepal, the active engagement of community based organizations ensured inclusive decision making, community empowerment, raising voices of social issues, and effective service delivery that elevated 
social and economic condition of the grassroots communities. The recent outcome of the community based organizations' engagement assisted to institutionalize the "bottom-up" approach at the grassroots level. However, the Acts, regulations, and policies were not inclusive in practical realm; not only did they fail to transfer power to the local level, but they also entrenched the Centre's political interests in the name of decentralization. Experiences reveal that the complexities of these legal procedures strengthened the centralization process and increased the influence of political and local elites in the community power structure and local resource mobilization. The following table illustrates the effectiveness CBOs in service delivery mechanism at the grassroots level.

Table 1: CBOs effectiveness in service delivery mechanism at the grassroots level

\begin{tabular}{|c|c|c|c|c|c|c|}
\hline \multirow[b]{2}{*}{ Activities } & \multirow{2}{*}{$\begin{array}{l}\text { Number } \\
\text { of } \\
\text { Indicators } \\
\text { (I) }\end{array}$} & \multicolumn{5}{|c|}{ CBOs types } \\
\hline & & $\begin{array}{l}\text { CFUGs } \\
(n=31)\end{array}$ & $\begin{array}{c}\text { CODGs } \\
(\mathrm{n}=53)\end{array}$ & $\begin{array}{c}\text { WDGOs } \\
(\mathrm{n}=26)\end{array}$ & Average & Description \\
\hline $\begin{array}{l}\text { Consolidation } \\
\text { of enabling } \\
\text { environment }\end{array}$ & 5 & 0.46 & 0.47 & 0.41 & 0.45 & $\begin{array}{l}\text { Weak to } \\
\text { Moderate }\end{array}$ \\
\hline $\begin{array}{l}\text { Addressing } \\
\text { community } \\
\text { related social } \\
\text { issues }\end{array}$ & 5 & 0.59 & 0.41 & 0.38 & 0.46 & $\begin{array}{l}\text { Weak to } \\
\text { Moderate }\end{array}$ \\
\hline $\begin{array}{l}\text { Power sharing } \\
\text { approach }\end{array}$ & 5 & 0.38 & 0.56 & 0.31 & 0.42 & $\begin{array}{l}\text { Weak to } \\
\text { Moderate }\end{array}$ \\
\hline $\begin{array}{l}\text { Strengthening } \\
\text { organisational } \\
\text { capacity }\end{array}$ & 5 & 0.54 & 0.51 & 0.37 & 0.47 & $\begin{array}{l}\text { Weak to } \\
\text { Moderate }\end{array}$ \\
\hline $\begin{array}{l}\text { Resources } \\
\text { generation and } \\
\text { mobilisation }\end{array}$ & 5 & 0.34 & 0.51 & 0.44 & 0.43 & $\begin{array}{l}\text { Weak to } \\
\text { Moderate }\end{array}$ \\
\hline Average & & 0.46 & 0.49 & 0.38 & 0.45 & $\begin{array}{l}\text { Weak to } \\
\text { Moderate }\end{array}$ \\
\hline
\end{tabular}

Table 1 illustrates the CBOs' effectiveness at the grassroots level which felled weak to moderate categories. The functional index of CBOs capability shows all five functions were endured 
weak to moderate $(\mathrm{CI}=0.45)$. Among the functional activities, CBOs greater capacity remained in strengthening organisational capacity $(\mathrm{CI}=0.47)$ followed by addressing community related social issues $(\mathrm{CI}=0.46)$ and consolidation of enabling environment $(\mathrm{CI}=0.45)$. While, CBOs effectiveness on power sharing approach $(\mathrm{CI}=0.42)$ and resources generation and mobilisation $(\mathrm{CI}=0.43)$ activities remained worsening. Overall, $\mathrm{CBOs}$ functional efficiency and their service delivery mechanism was being weak to moderate in the study area that indicated the formation process of CBOs was led either by structural crisis or by vested interest of public and donors organisations. The occurrence of self-initiation in the construction of CBOs by the people was limited. According to public perception, the sponsored CBOs were highly powerstructured; more concerned with resources, upwardly accountable to the funding agencies, and lacked inclusiveness in their leadership. Thus, they were strongly influenced by political agendas and veered away from volunteerism and social movements against injustice. However, some CBOs were conscious of the people's needs and by nature of their functions were less political, but in such cases lacked resources and absence of technical capabilities. The consequence of this was that not only was these CBOs unable to meet public needs and demands, but also faced declining membership and increasing dysfunctionalism.

\section{Discussions}

In Nepal, some CBO groups were either constructed by the certain interest groups or many were inclusively elite dominance. These were the apparent explanations of the governance impaired at the grassroots level. These factors adversely limited the communities' access to service delivery mechanism in many ways. First, many CBOs faced institutional crisis so they could not adopt governance in their development initiatives. Second, in spite of the presence of a governance crisis, some CBOs were facing structural complexities in the service delivery mechanism. Third, governance crisis was the reason of power politics and concealed interest that hindered in the working culture of CBOs. Fourth, capacity constraint was a big anomaly of governance that limited the CBOs 
for their governance related functions. Finally, resources paucity contributed a negative consequence on the levels of community governance effectiveness.

\section{Institutional inefficiency}

Deficiency of institutional integrity is a major cause of the impaired community governance at the grassroot level. In the late 1970s, the Rapti Integrated Rural Development Project was commenced to reinforce the partnership between the central government and grassroot communities and deliver the basic services at the grassroots (Rondinelli, 1983). This joint effort, however, neglected the traditional community governance system and permitted the rural elites in the power structure to pay even less attention to legitimisation and participation of local communities, captured all possible alternatives, created a monopoly in the service system, and destroyed public motivation in institutional development.

Experiences further indicate that basic service delivery was determined by political elites. They engaged unnecessarily in the service mechanism and utilised the system according to their needs. Evidence shows their actions were either illegal or had no useful purpose for the communities. Edmunds and Wollenberg (2001) explain that the local elites in Nepal are an inbuilt system of society having substantial influence on local institutions and communities in project selection, implementation and harnessing resources. Most of the resourceful CBOs were captured by the local elites. In these projects, elite domination occurred in four stages. First, their entry was as facilitators, supporters and enablers. They intentionally involved themselves in the people's institutions. Second, they gradually captured the groups' social capital and decision-making processes. Third, they began to capture the physical assets particularly natural resources, cooperative-generated finances and government and donor funds. Finally, they utilised these for their political benefit. This cycle of events was the prime reason for the poor institutional mechanism that undermined the community governance process. Gauli and Hauser (2009) agree that the Nepalese Community Forestry Program was criticised for being 
dominated by elites who provided greater benefits to the better-off, than those provided to the poor.

Chambers (2006) argues that the attitudinal crisis and facilityoriented mentality of the development agencies, and other motivational factors limited service access in remote areas. The closely bonded relationship developed between service actors (state and non-state) and local elites captured the services and made them less accessible, more complex and badly compromised in terms of quality. This collusion created a scarcity of resources and a problem in accessibility for the poor and marginal groups. Thus, the delivery of services in these areas, and the formulation and preservation of voluntary community organisations, became a bigger challenge for community governance. Additionally, some factors caused this chaotic situation and made the people's institutions ineffectual. First, the isolated actions of the government and lack of incentive of nongovernment sectors discouraged community indigenous governance practices. Only certain sectors and classes, at the expense of the larger sections of the population, benefited. Secondly, it promoted a dependency syndrome. For example, community dependency on leadership and the latter's on the developing agencies, caused institutional decay and dysfunctionality, and inclined the leadership towards corruption

Post-1990, the new democratic government reformed many policies under the framework of neoliberalism to enhance the privatisation, denationalisation and deregulation, To enable this development, local governments (LGs) were upgraded to 'development coordinators' at the intermediate and grassroots level. However, unstructured and insufficient policy guidelines of local government failed to meet the national interest in governance. Experiences indicate that such guidelines were not only politicised, but also converted local government into a regulative institution of the central government. Consequently, these institutions became more bureaucratic, lethargic and unaccountable. Likely, grassroots organisations were politicised as they did not pay attention to the members' interests, nor did not hear members' grumblings and grievances, nor follow the institutional rules and regulations. Most of the CBO groups' activities lacked documentation. They were 
reluctant to uphold group policies, rule and regulations or had no policies and programs; they bypassed a public auditing and public hearing system, regular group meetings, and neglected the people's participation.

Matunhu (2011) argues that the major deficiency in developing countries is absence of a clear policy framework and a commitment to implement it. This makes for community difficulties in accessing services. At the same time, government bureaucrats, donor technocrats, and political elites often undermine community participation and their institutional roles in participatory development. Regardless such realities, social mobilisation approach helped transform rural livelihoods through improved community health and sanitation behaviour that lowered the maternal and child mortality rate, increased school enrollments and improved access to market facilities for agricultural products, reduced influence of middle-men in determining the prices of commodities, and an increased annual per family income. However, ambiguous agreements between the government and donors, an inequitable policy for group formalisation, inappropriate power devolution, autonomy, and the legitimisation process contributed much unevenness in $\mathrm{CBO}$ groups.

After the enactment of LSGA in 1999, the participatory planning process enriched the delivery system to some degree. However, due to the excessive influence of local political actors, there could be no miraculous change at the community level. By contrast, the planning process became a bargaining instrument for political leaders and a means of building relationships and attracting donor programs, with which to line their pockets. Likewise, the LSGA, and the Forest Master Plan could not become consensual documents because they granted power only to bureaucrats, political persons, and technically-wise elites, who could define their approach according to their expected benefits.

Structural complexities

Social factors such as attitude, legacy, ethnicity, family status, economic class, and awareness level and locality play a key role in effective community governance. Social structure is one of the key knights of community; it was constituted in three dimensions. 
First, it instituted the caste system which governs people's attitude, culture and social stratification. Secondly, community was ruled by the patrimonial system, which is related to legacy, culture and practices. Thirdly, social values were dominated by materialism. This stratified the whole of communities and affected people's confidence, relationships and practices.

Many experiences show that social structure legitimises the social organisation. However, three distinct characteristics - patronclient relationships, structural legacy, and social and economic exclusion contribute directly to poor community governance. The prime reasons were CBOs influenced by the hierarchy, local power structure, resource politics, and donors' intentions. This had not only created ambiguities for CBOs, but also encouraged the elites to jeopardise the BSDS. Some examples found that the head positions of the groups were captured by Jamindar (feudal elites). They were not conscious about community voices and did not inform them about major decisions, and financial transactions. Similarly, they did not distribute benefits, and other opportunities, equally among all members.

Upreti and Müller-Böker (2010) report that these sort of practices are part of the structural legacy of the feudal system that led weaker segments of society to lose interest in local democracy, governance, and the effective implementation of programs and actions. Although the provision of Nepalese Constitution of 2007 provided democracy for all diverse groups and channels to express their views openly, as well as to declare their identities and rights as citizens, leadership has remained largely confined to males and the so-called higher castes in society. Many participants stated that democratic practice at the community level had ceased to be inclusive. There were several reasons for this. First, the people themselves were not ready to participate in this process due to their lack of awareness and inadequate orientation. Secondly, conspiracies and unfair actions of the political parties and development partners deflated less powerful sectors of communities. Thirdly, the decentralisation of policy formulation and reformulation process from central to local was very technocratic, mechanised and overly formalised. Fourthly, CBO groups were less capable. The reforms which were introduced 
invariably functioned in a 'trickle down' manner, leading to a win or lose situation at the community level. This situation enabled only people who have voices, power, and wealth could articulate the issues and convince the development partners, so that they could get the chance to participate in different groups activities and benefit from them. This practice excludes many community people and organisations from the community building system, democratic practice, and overall governance process.

\section{Power politics and concealed interest}

At the community level, all CBO groups, executive leadership and key members were politically connected, or their actions were intricately associated with individual interests and hidden agendas. These vested interests meant that they no longer acted as agents of social change, but rather as politically motivated actors that created patronising, exclusionary and particularistic system at the grassroots level. Stiefel and Wolfe (1994) have coined a term 'difference in rationalities', to describe conflicting interests of the partners. They further point out that varied interests persist in $\mathrm{CBO}$ engagement at the grassroots level. The empirical evidence also points out that most CBOs did not share a common interest with the people, nor a common vision or objective. Such characteristics were facilitated by political and feudal groups, who were normally represented as middle class Tatha Bathas (social elites) families. They restricted the participation of poor Dalits and Tharus in executive positions and decision making.

Such actions resulted in CBOs being less inclusive and paying little attention to policies, guidelines and legal provisions. This power retaining attitude in many groups caused the decay of community governance, democracy and empowerment agendas and eroded the social cohesiveness at the community level.

These impositions created undue hurdles and unnecessary pressures for the community to move away from communityowned indigenous system to a forced and fabricated framework. The empirical findings further indicate that the pre-conditions of development agencies for matching funds, the formulation of parallel institutions, and denial of the existent coordination and 
levels of governance, led to the decline of community interest in their institutions, as well as their participation in planning and implementation. This created many distortions and institutional deficiencies at the community level and led to increasing dependency of communities in the long term. This dependency meant that while CBO groups become dependent on supporting agencies and their resources, members received the tag of a single agency. The explanations of general members show that this type of affiliation was of value to the leadership, whereas the general members received minimal benefit from the service opportunities. Similarly, many developing agencies encouraged the people to be part of community program and supported all kinds of public demands and addressed community needs. While doing this, however, they discouraged the community from building relationships with other developing agencies. This developing agency behaviour not only disrupted coordination and linkages in development, but also did not know how to contact other agencies and had no capacity to continue current endeavours.

Likewise, there were several areas of conflict of interest between general members and the executive board, which destroyed community governance and institutional efficiency at the community level. According to empirical evidence, the reasons for these conflicts of interest centered on resources and their mobilisation, skills and knowledge, project selection and implementation, and leadership.

This process hindered community members' ability to organise and they have difficulty in actively involving themselves in identification of problems, planning, decision making and action, to meet their needs and resources, with or without support of government or NGOs. In contrast, some believe that BSDS is the prime responsibility of the government and its functionaries. The people thought the government could, or should, deliver basic services such as basic infrastructure and social and physical amenities to the communities. However, the government functionaries advocate that the state has devolved many powers, functions and resources to the community level. They further claim that communities were not sufficiently self-oriented, and that CBOs were not fully capable 
of receiving this power and authority. Hence most of the powers, authorities and resources were captured by the local elites. At the same time, the government staffs are unresponsive, behaving as adversaries of the people. They kept the political elites in the centre and us on the periphery. They thought that only politicians and elites could maintain power at the community level through their hierarchical connections. More important, their negative attitude suggested that the community demands are 'unnecessary complexities and a burden'.

In the study area, there was serious dispute among the service organisations about their existence and reputation; therefore these organisations were not interested in cooperating or forming linkages. There was neither strategic alliance established among the development agencies, nor a structured framework of CBO groups developed to mobilise the service functions.

In Nepal, there has been a serious absence of local authority in local government for more than a decade. This vacuum has led to misuse and misallocation of development resources, and misguided community governance, democratic practices and leadership of the local bodies, at the grassroots level. CBOs are regarded as the best institutional instrument, to fill the decision making and implementation gap at the grassroots level. However, their lack of capacity, cultural engagement with the external powers, resource constraints, and conflict of sectoral interests, led to inefficient CBO operations. At the same time, the government decided to form the all-party mechanism as an interim arrangement to fill this vacuum, and carry on service delivery and development work at the local government level. However, the trend shows that existing political mechanisms were not only unaccountable and impenetrable by the people, but that they also encouraged unprecedented corruption and irregularities in the local bodies. This behaviour encouraged partiality and exclusion at the community level.

These actions of the government created manifold difficulties and challenges for $\mathrm{CBO}$ groups, especially those that were marginalised. Thus, the continued absence of elected leadership jeopardised community governance at the grassroots, and as a consequence of reduced social accountability, further exposed public funds to misuse and corruption. 


\section{Capacity limitation}

Like other developing countries, the communities in Nepal faced several constraints in accessing education, health, mobility, safe drinking water, and other essential services due to the poverty, and many community organisations faced difficulties in providing these basic services. In order to address this, service organisations gave priority to enhancing the managerial and organisational capacities of local institutions through effective governance. In Nepal, the government has adopted a 'participatory' approach since the Eighth Five Year Plan (1992-1997), which enlisted the people's participation in the process of service delivery (Pandit, Wagley, Neupane, \& Adhikary, 2007). This broadened the scope of CBOs as the major instrument for service delivery at the community level.

However, CBOs were unable in many cases to prove their honesty and efficiency in effective service delivery and execution of service functions. For example, the government has annually increased the volume of grants for local development, in which local bodies are recognised as development coordinators for program formulation and resource delivery. However, lack of capacity and the powerful influence of political parties meant that the local bodies were unable to reach the community itself, or manage resources in a satisfactory way. At the same time, communities themselves were not identifying problems, managing and utilising the budgetary allocations, and presenting positive results.

The findings further show the lack of CBO ability in facilitation, interaction and communication. This had several implications for the community regarding their access to basic services. Firstly, there was a greater inequity in sharing the benefits; there were great differences in the amount of time it took to form the various CBO groups. Some were constituted almost immediately, but others took years. Most CBOs were categorised as founder members or new members, based on their entry. The founder members usually received more opportunities, while new members received the minimum. In this respect, CBOs failed to support all members equally.

Secondly, the LSGA provisioned 33 percent women's and 10 percent Dalit and ethnic minority participation in decision making. 
An allocation of 10 percent of resources for women's welfare programs, and another 10 percent for Dalit and ethnic groups, from the local government and sectoral line agencies' annual budget was provided for. Owing to a lack of capacity and awareness in proposal submission, project identification and cost estimation, these groups' participation was not effective and resources were not managed efficiently, which led these resources ending up in the hands of the elites.

Thirdly, the rural areas were most in need of infrastructure and rural communities demanded that infrastructure projects receive priority. However, when the resources to implement the projects arrived, many groups, as well as members, did not have the vision or confidence to drive the projects. The outcome of this was that many local elites took decisions to manage projects, on behalf of the communities. Fourthly, most of the leadership positions in the groups were occupied by school teachers, ex-local government leaders, unemployed educated youths and the rural feudal elite. There were many instances of these elites grabbing the benefits meant for the illiterate, or those lacking an understanding of their entitlements, as the former made the CFUGs more bureaucratic, centralised and elite guided, for this purpose. Further, the elites, who grabbed power and resources, lacked the knowledge and information necessary for innovation,which forced them to depend on the District Forest Office and federation of forest users, and thus they limited themselves to sectoral agendas or political issues.

\section{Resources paucity}

Most of the CBOs at the community level faced a scarcity of resources, which made them more dependent on government organisations or outsiders, particularly donors and NGOs. These organisations and their officials generally displayed a paternalistic attitude, which ignored the democratic process and full participation of communities. Experiences point out that they not only rejected the participatory decision making system in their support system, but also imposed a dependency in service delivery system. Malla (2001) argues that this attitude created domination and a patronising client relationship in decision making, and manipulated information 
and communication that deprived classes of their access to services.

In order to deliver equitable services to a community, it is imperative to allocate the necessary physical assets or funding resources, required to improve the service system and encourage public participation. Like other developing countries, community service delivery in Nepal was the responsibility of central governments, community organisations or private enterprises. This was insufficient, ineffective and sporadic, due to the top-down approach of central government or the profit-oriented motives of CBOs and the private sector. However, some examples show that multi-actor collaborations made significant improvements on the CBOs' lack of incentives, inadequate funds and absence of technical expertise. Addressing the issue of the government's reluctance and lack of awareness and coordination, in the community service system in poor areas

Apart from these problems, the legitimisation process provides a significant starting point for the institutionalisation of CBO groups, so that they can receive the resources and establish partnerships with development agencies. Experiences indicate that legitimisation of CBOs was not only a process for legal recognition, but also the instrument for social accountability, institutional capability and guarantee of resources. The absence of formal legitimacy of the CBOs meant they did not receive any funding support from the sectoral line agencies.

Some experiences demonstrate that the partnerships between resource agencies and $\mathrm{CBO}$ in many cases brought much prosperity and resolved many uncertainties. For example, the partnership with communities for school management, drinking water supply schemes, irrigation projects, and the number of public-private partnership projects for forest products, agricultural products, such as ginger production in, all were able to mobilise local resources at the community level. Although these projects enabled the local communities and their institutions to make themselves self-reliant, the imperfect market network, influence of elites and middle-men, as well as technical and financial constraints, still created problems at the community level. 
In late 2000, the government promoted an approach of 'sectoral devolution' for agriculture, livestock, education, health and postal service, to increase the communities' stake, improve service delivery and enhance community governance at the grassroots level, and fill the gap between communities and their practice of democracy. At the same time, the government encouraged the people, mainly from the marginal sectors and community based institutions, to become involved in the policy design process, through a range of planned mechanisms such as participatory planning, implementation and monitoring. This indicates that government priority was to encourage the local communities in identifying needs, formulating plans and programs and implementing them, to provide accessibility, sustainability and ownership, in terms of the service delivery mechanism. However, lack of resource allocation to community projects from the central government, and political influence in local government, resulted in a low level of trust in local communities.

\section{Conclusions}

Community governance in the study area has not only been involved in maintaining democratic practices and public access to the basic service delivery system, but also in empowering the capacity of communities and their actors to ensuring sustainable service delivery. Although many groups at the community level have been engaged in multi-layer matters, the trend shows that many micro and macro level factors are causing their passage from specific to polycentric issues. The results of negative inter-correlation with six variables indicate structural problems facedby CBOs such as upward accountability, inordinate dependency on others (viz. local elites, government and donor agencies), institutional crisis, socio-economic hierarchical rigidity in communities, resource misuse and service delivery manipulation. These affected the effectiveness of CG in many ways. First, lack of awareness and inadequate orientation discourage communities from participating in community affairs. Secondly, the development partners act unfairly insofar community matters are concerned. Thirdly, the policy formulation and reformulation process is very technocratic, mechanised and over- 
formalised. Fourthly, CBO groups demonstrate limited capability. And, last but not least, group leaders are politically connected or their actions are intricately associated with individual interests or hidden agendas.

Post-1990, the government transformed local government institutions into development coordinators at the intermediate and grassroots level. LSGA along with the Good Governance Act of 2006 supports the objectives, policies, and principles of the existing local self-governance system through the mobilisation of local communities. However, evidence indicates that CBOs are directly induced by many factors such as institutional policies;socioeconomic structure, power politics and interest, capacity constraint in community organisations, and resource constraints in community organisations. These create complexities in decision-making and have the potential to make them less capable and more disorganised. The basic service delivery system thereby suffers.

\section{References}

Adhikari, B., \& Lovett,J. C. (2006). Institutions and collective action: Does heterogeneity matter in communitybased resource management? The Journal of Development Studies, 42(3), 426-445. doi: 10.1080/00220380600576201.

Agrawal,A., \& Gupta, K. (2005). Decentralization and participation: The governance of common pool resources in Nepal's Terai. World Development, 33(7), 11011114. doi: 10.1016/S0305-750X(05)00105-1.

Banner, G. (2002).Community governance and the new centrallocal relationship. International Social Science Journal, 54(172), 217-231. doi: 10.1111/14682451.00373.

Baral, L. R. (2012). Nepal, nation, state in the wilderness: Managing state, democracy, and geopolitics. New Delhi: SAGE Publications.

Bardhan, P., \& Mookherjee, D. (2005). Decentralizing antipoverty program delivery in developing countries. Journal of Public Economics, 89(4), 675-704. doi: 


\subsection{6/j.jpubeco.2003.01.001.}

Bardhan, P.(2002). Decentralization of governance and development. The Journal of Economic Perspectives, 16(4), 185205. doi: $10.1257 / 089533002320951037$.

Beeson, M., \& Islam, I. (2005). Neo-liberalism and east Asia: Resisting the Washington consensus. The Journal of Development Studies, 41(2), 197-219. doi: $10.1080 / 0022038042000309214$

Bekkers, V. J. (2007). Governance and the democratic deficit: Assessing the democratic legitimacy of governance practices. Hampshire, London: Ashgate Publishing. Bingham, L. B., Nabatchi, T., \& O'Leary, R. (2005). The new governance: Practices and processes for stakeholder and citizen participation in the work of government. Public Administration Review, 65(5), 547-558. doi: 10.1111/j.1540-6210.2005.00482.x.

Booysen, F. (2002).An overview and evaluation of composite indices of development. Social Indicators Research, 59(2), 115-151.

Bowles, S., \& Gintis, H. (2002). Social capital and community governance. The Economic Journal, 112(483), 419-436. doi: 10.1111/1468-0297.00077.

Carter, L., \& Bélanger, F. (2005). The utilization of e-government services: Citizen trust, innovation and acceptance factors. Information Systems Journal, 15(1), 5-25. doi: 10.1111/j.1365-2575.2005.00183.x.

Chambers, R. (1995). Poverty and livelihoods: whose reality counts? Environment and Urbanization, 7(1), 173204. doi: 10.1177/095624789500700106.

Chambers, R. (2006). Vulnerability, coping and policy (editorial introduction). IDS bulletin, 37(4), 33-40. doi: 10.1111/j.1759-5436.2006.tb00284.x.

Cheshire, L., \& Lawrence, G. (2005). Neoliberalism, individualization and community: Regional restructuring in Australia. Social Identities, 11(5), 435-445. doi: 10.1080/13504630500407869.

Cheshire, L. (2000). Contemporary strategies for rural community 
development in Australia: A governmentality perspective. Journal of Rural Studies, 16(2), 203215. doi: 10.1016/S0743-0167(99)00054-6.

Clark, D. A. (2005). The Capability approach: Its development, critiques and recent advances (pp. 1-18). Manchester: Economic and Social Research Council (ESRC).

Coombs, W. T. (2007). Protecting organization reputations during a crisis: The development and application of instuitional crisis communication theory. Corporate Reputation Review, 10(3), 163-176. doi: 10.1057/ palgrave.crr.1550049.

Commins, S. (2007). Community participation in service delivery and accountability. Los Angeles: University of California.

Cilliers, J., \& Sisk, T. D. (2013). Assessing long-term state fragility in Africa: Prospects for 26'more fragile countries. Colorado: Institute for Security Studies, University of Denver.

Dahal, D. R. (2010). Reflection on leviathan: State and governance in Nepal (Vol. 58): Heidelber. Universitätsbibliothek der Universität $\mathrm{g}$.

Edmunds, D., \& Wollenberg, E. (2001). Historical perspectives on forest policy change in Asia. Environmental History, 6(2), 190-212. doi: 10.1016/j.forpol.2015.05.011.

Escobar, A. (1988). Power and visibility: Development and the invention and management of the Third World. Cultural Anthropology, 3(4), 428-443. doi:10.1525/ can.1988.3.4.02a00060.

Fox, J. (1993). Forest resources in a Nepali village in 1980 and 1990: the positive influence of population growth. Mountain Research and Development, 89-98. doi: http://dx.doi.org/10.1659/02764741(2001)021[0175:LCCATA2.0.

Gauli, K. \& Hauser, M. (2009). Pro-poor commercial management of non-timber forest products in Nepal's community forest user groups: Factors for success. Mountain 
Research and Development, 29(4): 298-307. doi: $10.1659 / \mathrm{mrd} .00051$.

Gaventa, J. (2004). Strengthening participatory approaches to local governance: learning the lessons from abroad. National Civic Review, 93(4), 16-27.doi: 10.1002/ ncr.67.

Grindle, M. S. (2007). Good enough governance revisited. Development Policy Review, 25(5), 533-574. doi: 10.1111/j.1467-7679.2007.00385.x.

Habib, A., \& Taylor, R. (1999). South Africa: anti-apartheid NGOs in transition. Voluntas: International Journal of Voluntary and Non-profit Organizations, 10(1), 7382.

Hamilton, D. K., Miller, D. Y., \& Paytas, J. (2004). Exploring the horizontal and vertical dimensions of the governing of metropolitan regions. Urban Affairs Review, 40(2), 147-182.doi:10.1177/1078087404268077.

Halachmi, A. (2005). Governance and risk management: challenges and public productivity. International Journal of Public Sector Management, 18(4), 300-317.doi:http://dx.doi. org/10.1108/09513550510599238.

Hulme, D., \& Shepherd, A. (2003). Conceptualizing chronic poverty. World Development, 31(3), 403-423. doi:10.1016/S0305-750X(02)00222-X.

Huntington, S. P. (1991). The third wave: Democratization in the late twentieth century (Vol. 4). University of Oklahoma Press.

Illing, C., \& Gibson, J. (2007). Rural water service provision by municipalities and CBOs: Performance milestones and KPIs. Water SA, 30(5), 549-554.

Iversen, V. (2003). Intra-household inequality: a challenge for the capability approach? Feminist economics, 9(2-3), 93-115. doi:10.1080/1354570032000080868.

Kerno, S. J. (2008). Limitations of communities of practice. Journal of Leadership \& Organizational Studies, 15(1), 6978. doi:10.1177/1548051808317998. 
King, J. A. (2008). Institutional approaches to judicial restraint. Oxford Journal of Legal Studies, 28(3), 409-441. doi:10.1093/ojls/gqn020.

Kohli, A. (2004). State-directed development: political power and industrialization in the global periphery. London: Cambridge University Press.

Khanal, R. (2006). Local governance in Nepal: Democracy at grassroots (First ed.). Lalitpur: Smriti Books.

Lewis, D., \& Kanji, N. (2009). Non-governmental organizations and development. Taylor \& Francis.

Matunhu, J. (2011). A critique of modernization and dependency theories in Africa: Critical assessment. African Journal of History and Culture, 3(5), 65-72. doi: $10.1177 / 1748048513504166$

Mahanty, S., Guernier, J., \& Yasmi, Y. (2009). A fair share? Sharing the benefits and costs of collaborative forest management. International Forestry Review, 11(2), 268-280. doi:http://dx.doi.org/10.1505/ ifor.11.2.268.

Malla, Y. (2001). Changing policies and the persistence of patronclient relations in Nepal: stakeholders' responses to changes in forest policies. Environmental History, 287-307. doi:10.2307/3985088.

McEwan, C. (2003). Bringing government to the people': women, local governance and community participation in South Africa. Geoforum, 34(4), 469-481. doi:10.1016/j.geoforum.2015.06.026

Mehrotra, S. (2006). Governance and basic social services: ensuring accountability in service delivery through deep democratic decentralization. Journal of International Development, 18(2), 263-283. doi:10.1002/jid.1219.

Meyer, J. W. (2008). Reflections on institutional theories of organizations. In R. Greenwood, C. Oliver, R. Suddaby \& K. Sahlin-Andersson (Eds.), The Sage Handbook of Organizational Institutionalism (pp. 790-811). California: SAGE. 
Migheli, M. (2011). Capabilities and functionings: The role of social capital for accessing new capabilities. Review of Political Economy, 23(1), 133-142. doi:10.1080/09 538259.2011 .526297$.

Murray, C. (2012). Coming apart: The state of white America, 1960-2010. New York: Three Rivers Press.

NPC. (2003b). Thirteenth plan: Poverty reduction strategy paper (2002-2007). Kathmandu: National Planning Commission, Government of Nepal.

Nsubuga, J. K., \& Olum, Y. (2009). Local governance and local democracy in Uganda. Commonwealth Journal of Local Governance (2), 26-43. doi:10.1177/0020852309359049

Ojha, H.R., Cameron, J., Kumar, C. (2009). Deliberation or symbolic violence?: The governance of community forestry in Nepal. Forest Policy and Economics 5-6 (11), 365-374.doi:10.1016/j.forpol.2008.11.003.

Ojha, H. (2006). Techno-bureaucratic doxa and the challenges of deliberative governance: The case of community forestry policy and practice in Nepal. Policy and Society 25(2), 131-175.doi:10.1016/S14494035(06)70077-7.

Ostrom, E. (2007). A diagnostic approach for going beyond panaceas. Proceedings of the National Academy of Sciences, 104(39), 15181-15187. doi:10.1073/ pnas.0702288104.

Pandit, B. H., Wagley, M. P., Neupane, R. P., \& Adhikary, B. R. (2007). Watershed management and livelihoods: lessons from Nepal. Journal of Forest and Livelihood, 6(2), 67-75. doi:

Perez., C. A. (1999). Participation in development: Evolution of a philosophy. In M. K. Shah, S. D. Kambou \& B. Monahan (Eds.), Embracing Participation in Development. The United States Agency for International Development and The Andrew W. Mellon Foundation.

Pillora, S., \& McKinlay, P. (2011). Local government and 
community governance: A literature review (pp. 1-29): Sydney. Australian Centre of Excellence for Local Government, University of Technology Sydney.

Ramo, S., \& Clair, R. K. S. (1969). Cure for chaos: Fresh solutions to social problems through the systems approach. KNI, Incorporated Anaheim. California: TRW, INC., 1-141.

Reydon, B. P. (2006). Social embeddedness, institutions for rural land management and land grabbing: the cases of Afghanistan and Brazil. Paper presented at the colloque international "Les frontières de la question foncière - At the frontier of land issues", Montpellier.

Rhodes, R. (1996). The new governance: Governing without government. Political Studies, 44(4), 652-667. doi:10.1111/j.1467-9248.1996.tb01747.x.

Rondinelli, D. A. (1983). Implementing decentralization programmes in Asia: A comparative analysis. Public Administration and Development, 3(3), 181-207. doi:10.1002/pad.4230030302.

Ross, K., \& Osborne, S. P. (1999).Making a reality of community governance: Structuring government-voluntary sector relationships at the local level. Public Policy and Administration, 14(2), 49-61. doi: $10.1177 / 0952076708093250$

Roy, I. (2008). Civil society and good governance :(re) conceptualizing the interface. World Development, 36(4), 677-705. doi:10.1016/j. worlddev.2007.04.020.

Saito, M. (2003). Amartya Sen's capability approach to education: A critical exploration. Journal of Philosophy of Education, 37(1), 17-33. doi:10.1111/14679752.3701002 .

Sen, A. (1990). Development as capability expansion. Human development and the international development strategy for the 1990s. London: Macmillan. 
Sen, A. (2004). Capabilities, lists, and public reason: continuing the conversation. Feminist economics, 10(3), 77-80. doi:10.1080/1354570042000315163.

Scott, J. K., \& Fannin, J. M. (2006).Community decision support and the role of the public in regional policy analysis. The Journal of Regional Analysis and Policy, 37(2), 103-115.doi:10.1111/cjag.12027.

Shah, A. (2007).Performance accountability and combating corruption, In A. Shah (Ed.), Public Sector Governance and Accountability Series. Washington, DC: World Bank.

Shah, A. (2005). Public services delivery. Washington DC: World Bank Publications.

Stâhlber, G. K. (1997). Enhancing citizen and community participation. Gütersloh Bertelsmann Foundation Publishers.

Stiefel, M., \& Wolfe, M. (1994). A voice for the excluded: Popular participation in development: utopia or necessity? London: Zed Books.

Stoker, G. (1998). Governance as theory: five propositions. International Social Science Journal, 50(155), 1728.doi: 10.1111/1468-2451.00106.

Tamang, S., \& Malena, C. (2011).The Political Economy of Social Accountability in Nepal Kathmandu. Program for Accountability in Nepal.

Thorsen, D., \& Lie, A. (2000). What is neoliberalism? Norway: University of Oslo, Department of Political Science.

Török, R. (2005). The new institutional approach. European Integration Studies, 4(1), 53-59.

Uphoff, N. (1993). Grassroots organizations and NGOs in rural development: Opportunities with diminishing states and expanding markets. World Development, 21(4), 607-622. doi: 10.1016/0305-750X(93)90113-N.

Uphoff, N. (2004, 15-20 June 2002). Local communities and institutions: Realizing their potential for integrated rural development. Paper presented at the Role of 
Local Communities and Institutions in Integrated Rural Development, Iran.

Upreti, B. R., \& Müller-Böker, U. (2010). Livelihood insecurity and social conflict in Nepal. In B. Upreti \& U. MüllerBöker (Eds.). Kathmandu: Swiss National Centre of Competence in Research (NCCR) North-South.

Vidal, A. C., \& Keating, W. D. (2004). Community development: Current issues and emerging challenges. Journal of Urban Affairs, 26(2), 125-137. doi: 10.1111/j.07352166.2004.00191.x.

Walker, M. (2005). Amartya Sen's capability approach and education. Educational Action Research, 13(1), 103-110.

WaterAid. (2012). Dang: Drinking water and sanitation profile. Kathmandu: Water Aid Nepal and Feda WATSAN.

Weber, M., Driessen, P. P. J. \& Runhaar, H. A. C. (2011). Drivers of and barriers to shifts in governance: analysing noise policy in the Netherlands. Journal of Environmental Policy \& Planning, 13(2), 119-137. doi: 10.1080/1523908X.2011.572657.

Zafarullah, H., \& Huque, A. (2001). Public management for good governance: Reforms, regimes, and reality in Bangladesh. International Journal of Public Administration, 24(12), 1379-1403. doi: 10.1081/ PAD-100105944. 